\title{
Dinamika Peradaban Kampung di Bangka
}

\section{Rusydi Sulaiman}

IAIN Syaikh Abdurrahman Siddik Bangka Belitung, Indonesia abirusydi@yahoo.co.id

\begin{abstract}
Indonesia is known for its vast territory consisting of thousands islands. One of them is Pulau Bangka-an island which also includes many villages in the right and left row of roads with other completeness as the reality of the village in Bangka. Sociologically, the island is harmed because the form of the village in Bangka is more due to colonial policy in the middle of nineteenth century. It was different from previous village land inherited by the ancestors (Atok-Nek) in Bangka. This article focuses on early village discussions in Bangka named kampung with qualitative research methods sourced from data related to the subject matter. This research produces several subdiscussions, namely: village philosophy, archaeological data in Bangka, the history of kampung in Bangka, kampung and strengthening civilization. Kampung does not appear immediately in the history of Bangka, but there were in long process. Early Bangka people inherited some ranges; memarung, panggung, bubung kampung and nganggung. Then adopted by Malay Islam (urang lah). In philosophical Islam, there was a process of strengthening local wisdom values as a form of kampung civilization in Bangka island.
\end{abstract}

Keywords; Kampung, dynamic, kampung's civilization, kampung in Bangka

Accepted: 22-10-2019; published: 30-12-2019 Citation: Rusydi Sulaiman, 'Dinamika Peradaban Kampung di Bangka', Mawa'izh: Jurnal Dakwah dan Pengembangan Sosial Kemanusiaan, vol. 10, no. 2 (2019), pp. 190-213. 


\section{A. Pendahuluan}

ondisi geografis Indonesia yang rumit tidak kemudian mengurungkan niat para
petualang untuk menjamahnya. Tak terkecuali ulama yang berprofesi sebagai
penyebar Agama Islam. Tentu ada hal-hal yang menakjubkan yang menjadikannya lebih memiliki nilai plus bila dibandingkan dengan wilayah lain di dunia ini. Di luar dimensi keluasannya, Indonesia memiliki letak strategis, yaitu berada di titik persilangan antarbenua dan antar samudra - membuat kepulauan ini sejak lama menjadi kuala penyerbukan silang budaya dan peradaban dunia. Dan diprediksi bahwa Indonesia akan menampilkan senyawa arkeologi peradaban yang berlapis, tempat unsur peradaban purba, tua, modern, dan pasca modern hadir secara simultan. ${ }^{1}$ Apalagi disebut sebagai. "Taman Sari Dunia" - sebuah wilayah kepulauan yang kaya akan sumberdaya alam dan memotivasi bangsa-bangsa untuk mengenalnya lebih dekat.

Demikian halnya Pulau Bangka, sebuah pulau yang posisinya sangat strategis sehingga diminati banyak pendatang dari penjuru tanah air bahkan dunia luar. Sebenarnya secara geografis pulau tersebut letaknya tidak juga jauh, yaitu di seberang timur pulau Sumatra. Pulau ini bila ditempuh dari Jakarta melalui pesawat terbang, hanya menghabiskan waktu 50 menit hingga 1 jam. Pulau Bangka sangat mudah diakses sekarang dari arah manapun. Namun, kata "Bangka" memberi kesan makna tua - Tua Bangka, yaitu: sangat tua sekali. Hampir pasti sesuatu yang tua tidak digubris, tidak dipedulikan dan juga tidak diperhitungkan orang kebanyakan. Berbeda dengan yang muda, pasti dilirik, didekati bahkan terlalu diapresiasi. ${ }^{2}$

Sesungguhnya Bangka adalah pulau tua yang memiliki dinamika sejarah tersendiri. Pulau Bangka yang sangat strategis menghubungkan China, India, Arab dan kepulauan Nusantara ini memiliki luas $11.693 .54 \mathrm{~km} 2$, berbatasan dengan laut China

${ }^{1}$ Yudi Latif, 'Bhinneka Tunggal Ika: Suatu Konsepsi Dialog Keragaman Budaya', makalah dalam kegiatan, Dialog Sejarah dan Keragaman Budaya, diselenggarakan oleh Direktorat Sejarah dan Nilai Budaya, dirjen Kebudayaan kemendikbud, tanggal 29-30 Nopember 2013 di Hotel Ratu Serang Banten, p. 2 .

2 Beberapa istilah sebagai asal usul kata,"bangka", diantaranya adalah: pertama, wangka yang berarti timah sebagai barang tambang yang banyak ditemukan di Pulau Bangka; kedua, berdasarkan penamaan seorang bangsawan Bugis bernama Sri Gading yang menemukan jejak kehidupan di daerah sekitar rawa-rawa; ada pondok kecil dan mayat perempuan dan laki-laki pasca menetap di Johor. Maka disebutlah "Bangka"; ketiga, berasal dari kata "wangkang" (Bahasa Cina), berarti perahu. Perahu-perahu tersebut diperkirakan dibuat di daerah pesisir Kalimantan Barat yang terletak di utara laut Jawa, yaitu Bangka dan Belitung. Dan beberapa keterangan lain tentang asal usul nama Pulau Bangka. 
Selatan di sebelah utara, Selat Gaspar, selat Karimata dan Pulau Belitung disebelah timur, laut Jawa disebelah selatan, Selat Bangka dan Pantai Timur Pulau Sumatera di sebelah barat. Posisinya memanjang dari barat laut ke tanggara hampir $180 \mathrm{~km}$ berbentuk mirip kuda laut. Pulau tersebut terdiri dari rawa-rawa, dataran rendah dan bukit-bukit. Disekitar bukit-bukit terdapat hutan primer, adapaun di sekitar rawa-rawa terdapat hutan bakau atau mangrove. Rawa-rawa tersebut tidak jauh berbeda dengan rawa-rawa di Pulau Sumatera. Bukit tertinggi adalah bukit Maras (699 m) di Kabupaten Bangka dan bukit Menumbing (445 m) di kabupaten Bangka Barat. ${ }^{3}$

Sebelum pemekaran wilayah, Bangka awalnya terdiri dari 13 kecamatan, yakni: Kecamatan Sungailiat meliputi 12 kelurahan dan 12 kampung, Kecamatan Merawang meliputi 11 kelurahan dan 11 kampung, Kecamatan Belinyu meliputi 5 kelurahan dan 5 kampung, kecamatan Jebus meliputi 18 kelurahan dan 15 kampung, Kecamatan Muntok meliputi 11 kelurahan dan 11 kampung, Kecamatan Kelapa meliputi 10 keluragan dan 10 kampung, Kecamatan Pangkalpinang meliputi 9 kelurahan dan 9 kampung, Kecamatan Mendobarat meliputi meliputi 9 kelurahan dan 9 kampung, Kecamatan Sungaiselan meliputi 8 kelurahan dan 8 kampung, Kecamatan Koba meliputi 12 kelurahan dan 12 kampung, Kecamatan Payung meliputi 15 kelurahan dan 15 kampung, Kecamatan Toboali meliputi 12 kelurahan dan 12 kampung, dan Kecamatan Lepar Pongok meliputi 5 kelurahan dan 5 kampung. Total luas bangka yakni 11.614 .125 km2 dengan 129kelurahan dan 134 kampung. ${ }^{4}$ Kemudian berubah secara signifikan menjadi Provinsi Kepulauan Bangka Belitung terdiri 1 Kotamadya Pangkalpinang sebagai ibukota Provinsi, 6 kabupaten meliputi 2 kabupaten di Pulau Belitung dan 4 kabupaten di Pulau Bangka dengan beberapa pulau kecil disekitarnya.

Suasana iklim di Pulau Bangka sangat menyejukkan karena memiliki tingkat kelembaban yang sangat tinggi (76\% - 88\%). Menurut Schmidt - Ferguson sebagaimana dikutip oleh Akhmad Elvian, bahwa iklim di pulau ini tergolong iklim tipe A dengan jenis vegetasinya adalah hutan hujan tropis. Muslim penghujan dan kemarau dipengaruhi oleh

\footnotetext{
${ }^{3}$ Akhmad Elvian, Kotakapur dalam Lintasan Sejarah Bahari (Pangkalpinang: Dinas Kebudayaan, Pariwisata, Pemuda dan Olahraga Kota Pangkalpinang, 2011), p. 5; lihat juga Rusydi Sulaiman, dkk., dalam KP.Ja'far Addari: Ulama Kharismatik dan Bersahaja (Bangka: Madania Center Press, 2019), p. 21.

${ }^{4}$ Zuhdi Hadiono, 'Spirit Ayo Bangun Bangka Kite' dalam buku bunga rampai Kelekak Sejarah Bangka (Bangka: Dinas Kebudayaan dan Pariwisata Kabupaten Bangka, 2015), p. 318.
} 
dua musim angin; angin muson barat dan angin muson tenggara. Angin muson barat terjadi di Bulan Nopember, Desember dan januari di bagian utara Pulau Bangka. sedangkan angin muson tenggara dari arah laut Jawa. ${ }^{5}$ Musim tersebut sangat menguntungkan bagi para nelayan yang akan masuk ke perairan Pulau Bangka. Selat Bangka yang terletak di pantai timur Pulau Sumatera menjadi sangat strategis sejak masa kerajaan Sriwijaya bahkan hingga saat ini. Lalu lintas dari segala arah bertemu untuk menantikan angin yang cocok agar para nelayan bisa melanjutkan perjalanan. Pantai ini disebut, "Pantai Niaga Yang Disenangi" (The favoured commercial coast). ${ }^{6}$ Kini Pulau Bangka dan beberapa pulau kecil disekitarnya menjelma menjadi Kepulauan Bangka Belitung setelah sebelumnya berstatus bagian dari Propinsi Sumatera Selatan berdasarkan Undang-Undang Nomor 27 tahun 2000 tanggal 4 Desember tahun 2000 tentang pembentukan Propinsi Kepulauan Bangka Belitung.

Pribumi Bangka yang dikenal,"Urang Bangka" merupakan komunitas yang berabad-abad sebelumnya telah menetap di Pulau Bangka. Sebagaimana diketahui bahwa terdapat empat etnis, yaitu: Orang Darat, Orang Laut, Orang Cina dan Orang Melayu. Mereka dalam kehidupan sosialnya saling berinteraksi satu sama lain sehingga membentuk budaya tersendiri.7 Sebelum menjadi Melayu, penduduk pribumi Bangka disebut, "urang lom" (belum beragama karena belum berkhitan). Orang Melayu Bangka mungkin saja berasal dari luar pulau tersebut, karena sebutan Melayu yang agak awal berasal dari sebuah kerajaan yang berpusat di hulu Sungai Jambi. Diceritakan bahwa daerah tersebut pernah disinggahi oleh pendeta Budha asal China yang bernama I-Tsing pada tahun 644 M. Hal tersebut juga berhubungan dengan isi tulisan dalam Prasasti Kotakapur yang berbahasa Melayu. Artinya dalam periode kekuasaan Sriwijaya dimungkinkan sudah ada komunitas Melayu yang menetap di Pulau Bangka. ${ }^{8}$

Bila Melayu diidentikkan dengan Islam, maka hal tersebut baru muncul pada masa kekuasaan Kerajaan Pasai, yaitu pasca Majapahit, abad ke 14 M. Komunitas Islam sekaligus melayu tersebut tersebar dari Malaka ke penjuru Nusantara. Masyarakat

5 Elvian, Kotakapur, p. 6-7.

6 Ibid, p. 8.

7 Lihat Akhmad Elvian, Depati Amir; Pejuang Tangguh dan Berbahaya (Pangkalpinang: Dinas Kebudayaan, Pariwisata, Pemuda dan Olahraga, 2012)

${ }^{8}$ Sulaiman, dkk., K.H. .Ja'far Addari, p. 25. 
Melayu merupakan penduduk yang menetap di semenanjung Tanah Melayu (Malaya), Singapura, Thailand Selatan, Pesisir Timur Sumatera (tepi Selat Malaka dan Laut Cina Selatan), yaitu: Temiang, langkat, Deli Serdang, Asahan, Labuan Batu, Riau, Pesisir Jambi, Pesisir Palembang, Bangka, Belitung, selanjutnya wilayah Kalimantan Barat, Serawak dan Brunai serta beberapa wilayah diaspora seperti Kompong Chom (Kamboja), di Srilanka dan Afrika Selatan. ${ }^{9}$ Penduduk Melayu di Kepulauan Melayu disebut," The malay Archipelago". Orang Islam di Bangka adalah orang Melayu, berbahasa Melayu, memiliki adat istiadat Melayu yang kemudian berakulturasi dengan beberapa etnis lain di pulau tua tersebut.

Abdullah Idi menegaskan bahwa asal usul orang Melayu Bangka dapat diklasifikasi menjadi dua teori mengenai perpindahan mereka, yaitu: pertama, berasal dari suatu daerah di Indonesia yang pindah melalui Semenanjung kemudian menyeberang ke pulau-pulau terdekat, yakni: Kalimantan, Sumatera dan Fillipina; kedua, mereka berasal dari Cina Selatan menyeberang ke Kalimantan dan Fillipina. Orang-orang Melayu itu disebut, "kelompok Neolitik", dan seringkali dipanggil Proto-Melayu. ${ }^{10}$ Setelah itu penduduk luar eksodus ke daerah ini melalui jalur dagang dan beberapa jalur lain sehingga persentuhan tersebut berimplikasi terhadap peradaban dan kebudayaan penduduk. Proses yang disebut, a clash of civilization hampir pasti memberi pengaruh positif dan menjadikan mereka lebih baik.

Adapun etnis lain yang juga menetap di Pulau Bangka adalah orang Cina, juga disebut urang lom, karena belum beragama Islam. Orang Cina di Pulau Bangka mulanya adalah para migran pasca revolusi industri di Eropa yang dipekerjakan di sektor pertambangan timah. Di pertengahan abad ke $18 \mathrm{M}$, Kesultanan Palembang juga mendatangkan kuli-kuli Cina Daratan yang kemudian disebarkan di beberapa daerah di Pulau Bangka. ${ }^{11}$ Proses pembauran pun terjadi antara orang Cina dengan penduduk

\footnotetext{
${ }^{9}$ Elvian, Kotakapur, p. 10
}

${ }^{10}$ Masyarakat Proto-Melayu sudah mulai menetap dalam kelompok-kelompok besar di tepi laut dan muara sungai. Mereka membuka lahan sawah dan menagkap binatang, menangkap ikan di sungai dan juga di laut. Mereka juga melakukan barter secara terbatas. Dikalangan masyarakat pantai tersebut muncullah kelompok-kelompok individual yang diterima sebagai pemimpin, karena mereka lebih kuat dan memiliki status lebih tinggi dari kelompok-kelompok lainnya..Abdullah Idi, Bangka: Sejarah Sosial Cina Melayu, (Yogyakarta: Tiara Wacana, 2011), p. 13

${ }^{11}$ Abdullah Idi, Bangka: Sejarah, p. 4 
pribumi Bangka, komunitas Melayu. Orang Darat dan Orang Laut di Bangka yang merupakan pribumi Bangka yang juga disebut,"urang lom".12

Urang lom lain di pulau Bangka adalah orang laut. Mereka berdomisili di beberapa lokasi, yaitu: pantai Teluk Kelabat, Mantung (tempat berkumpul), Muara Sungai Kampa (Di Bangka Barat Laut), di Muara Kurau dan sebagian kecil Lepar. Mereka dikenal sangat handal di Perairan Malaya, menagkap tripang dan agar-agar. Sejak dulu mereka sudah terbiasa dihadapkan dengan situasi perairan yang rawan, begitu banyaknya perompakan terjadi di perairan Riau, yaitu wilayah yang terbentang dari Anambas Natuna hingga Bangka dan Belitung di sebelah selatan serta pantai Timur Sumatera hingga kalimantan Barat, dperkirakan 300 tahun sebelum masehi. ${ }^{13}$ Mereka disebut sebagai sea-base community, memiliki keterkaitan yang sangat kuat terhadap alam laut.

Dan Orang darat yang juga disebut,"orang Gunung (Hill-People) adalah mereka yang memiliki kegiatan primer, yaitu kegiatan berume dan berladang yang menghasilkan padi cerak dan padi ketan atau pulut. Mereka tinggal di di lokasi yang dekat dengan sumber mata air, tidak diatas bukit-bukit. ${ }^{14}$ Setelah itu mereka membentuk keluarga tertentu. Ikatan kekerabatan pada masyarakat pribumi Bangka ditentukan melalui prinsip garis keturunan dan ditentukan juga melalui istilah-istilah kekerabatan dalam menyebut dan menyapa yang digunakan pada lingkungan masyarakat dan keluarga. ${ }^{15}$ Prinsip yang dianut adalah garis keturunan bilateral, yaitu memperhitungkan pertalian

12 Abdullah Idi, Bangka: Sejarah, p. 16-17 Yang membedakan Orang Lom dengan komunitas lainnya adalah dalam sistem sosial dan sistem budaya yang bersumber dari tradisi nenek moyang dan tetap bertahan di tengah perubahan zaman. Tradisi leluhur terinternalisasi dalam diri melalui keyakinan bahwa mereka dilahirkan dari kekuatan alam semesta. Kesadaran tersebut menimbulkan kepercayaan antara diri (manusia) memiliki hubungan dialektika yang dinamis dengan lingkungan sekitar seperti hutan,tanah, air dan gunung serta makhluk hidup lainnya. Orang lom tidak mengenal ritual ibadah, tapi cukup melalui kontemplasi ketika akan berkomunikasi dengan alam dan nenek moyang. Lihat dalam Iskandar Zulkarnain dan Jamilah Cholillah, Memaknai Kearifan Sosial Budaya,"Orang Lom" Bangka, dalam buku bunga rampai, Kelekak Sejarah Bangka, (Bangka: Dinas Kebudayaan dan Pariwisata Kabupaten Bangka, 2015), p. 341

13 Abdullah Idi, Bangka: Sejarah, p. 18

${ }^{14}$ Kegiatan peladangan secara umum dimulai dari kegiatan mencarai lahan, membakar lahan hasil tebasan atau rebak, memanduk (membakar hasil tebasan yang tersisa, menggaleng (membuat ptak-petak lahan dengan susunan kayu ) dan memarung (menetapkan petak ladang untuk dibangun pondok ume atau panggung), nugal dan mene atau menanam lahan dengan padi cerak atau padi ketan (pulut) serta tanaman palawija lainnya seperti cadur dan timun darat. Lihat Elvian, Memarung, Panggung, Bubung, Kampung dan Nganggung, (Pangkalpinang: Dinas Kebudayaan,Pariwisata, Pemuda dan Olahraga Kota Pangkalpinang, 2015), p. 7-8

${ }^{15}$ Elvian, Memarung, Panggung, p. 34 
keluarga berdasarkan garis ayah dan ibu. Masing-masing memiliki kekuatan yang sama, baik kewajiban terhadap ayah maupun kewajiban terhadap ibu. ${ }^{16}$

Dalam perkembangannya, keempat etnis tersebut nampaknya saling mewarnai satu sama lain sehingga tidak ada yang lebih dominan. Dalam hal bahasa pun, orang Bangka memiliki beragam bahasa dengan dialek-dialek tertentu. Penduduk desa tertentu di Pulau Bangka terkadang kurang paham dengan logat bahasa penduduk desa sebelahnya. Hal tersebut menegaskan bahwa begitu uniknya keberadaan Pulau Bangka.

Pulau Bangka menjadi sangat strategis pasca diketemukannya timah oleh Bangsa Eropa. Beberapa negara di Eropa memperebutkan timah tersebut untuk kepentingan komoditas belaka dengan cara mengirimkan kuli-kuli Cina dan setelah itu mengkooptasi penguasa lokal. Dalam sejarahnya, tidak banyak sultan-sultan Palembang Darussalam yang peduli terhadap masa depan masyarakat Bangka, kecuali memiliki semangat mengeruk timah sebagai bahan tambang yang sangat bernilai untuk orientasi finansial. Akhirnya Pulau Bangka yang subur sebelumnya kemudian menjadi tercabik-cabik karena perilaku ceroboh dalam memanfaatkan sumber daya alamnya.

Satu keunikan yang dimiliki Pulau Bangka jauh sebelum kedatangan kolonial adalah pembentukan kampong, berawal dari tradisi yang panjang; memarung, paggung, bubung, kampung dan nganggung. Aktifitas yang bermula dari dalam hutan kemudian bergeser ke wilayah kerajaan sehingga menjadi lebih berperadaban. Terkandung di dalamnya nilai-nilai kearifan lokal warisan nenek moyang, atok-nek Urang Bangka yang kemudian di-Islamisasikan. Maksudnya nilai-nilai ajaran Islam mewarnai tradisi beberapa kampung di Bangka dan bahkan berlangsung hingga saat ini.

Islam di Pulau Bangka yang disinyalir telah lama sekali kemunculannya, bahkan jauh sebelum kedatangan kolonial Eropa. Kata "Bangka" adalah bentuk superlatif dari kata, "tua", yaitu "Tua Bangka", berarti sangat tua, tua sekali, dan tua renta. Disebut Pulau Bangka, karena usianya yang sangat tua dan mengandung sumber alam yang sangat banyak. Manusia dari manupun asalnya tertarik datang ke Bangka karena kandungan alam dan posisinya yang sangat strategis. Sangat dimungkinkan bila ulama penyebar agama Islam mengawali kedatangan mereka ke pulau tersebut dibandingkan dengan

\footnotetext{
16 Elvian, Memarung, Panggung, p. 35 lihat juga Rusydi Sulaiman, dkk., Ja'far ADDARI, p. 29
} 
wilayah-wilayah lain di Indonesia. Panglima Sarah adalah Raja Muda di Pulau Bangka pada abad ke XVI yang beragama Islam ditugaskan oleh Sultan Johor Malaysia pasca perang melawan bajak laut di perairan laut bangka. ${ }^{17}$ Bangka yang ketika itu sudah dipenuhi oleh kapal-kapal yang berlayar dari Malaka ke Jawa dan daerah lain mengindikasikan bahwa pulau tersebut memiliki daya tarik tersendiri bagi orang luar. Setelah itu dakwah Islam terus berlangsung dan bahkan mewarnai kehidupan masyarakat.

Dalam perkembangannya, Islam di Bangka memiliki corak keagamaan tersendiri. Secara garis besar diklasifikasi menjadi dua bagian, yaitu Islam tradisional dan Islam Modern. Satu hal yang dipertanyakan dalam tulisan ini adalah: pertama, bagaimana sejarah kemunculan kampung di Bangka?; kedua, bagaimana penguatan peradaban kampung di Bangka?

Tidak banyak literatur apalagi dalam bentuk hasil penelitian ilmiah tentang Bangka kecuali tulisan-tulisan tentang pertimahan dan gerakan sosial yang erat hubungannya dengan kepentingan politik Kolonial, seperti: karya Erwiza Erman, Menguak Sejarah Timah Bangka Belitung; dari Pembentukan Kampung ke Perkara Gelap, Penerbit Ombak Yogyakarta, 2009, dan karya Mary F. Somers Heidhues, Timah Bangka dan Lada Muntok; Peran Masyarakat Tionghoa dalam Pembanguanan Pulau Bangka Abad XVIII sd. XX, Yayasan Nabil Jakarta, 2008, serta beberapa buku lainnya, Satu tulisan agak awal berkaitan dengan masyarakat Bangka adalah karya Amran Harun, Pengaruh Agama Islam dalam Hukum Adat di Bangka, skripsi,Fakultas Hukum UGM Yogyakarta, 1967, dan karya Husneal Husen Abdullah, Sejarah Perjuangan Kemerdekaan RI di Bangka-Belitung, UI Press Jakarta, 1983. Berikutnya bermunculan beberapa tulisan yang cukup representatif karya Urang Bangka sendiri tentang sejarah Bangka, yaitu: Abdullah Idi, Bangka: Sejarah Sosial Cina Melayu, Tiara Wacana Yogyakarta, 2011; Zulkifli, Pengaruh Ulama Banjar dalam Tradisi Islam di Bangka, Jurnal Intizar, Vol.9, Tahun 1997; Zulkifli, Kontinuitas Islam Tradisional di Bangka, siddiq Press, 2007; Kartika Sari,dkk, Bangka: Mutiara Negeri Melayu, Madania Center Press, 2019; Rusydi Sylaiman, dkk., KH.Ja'far ADDARI: Ulama Kharismatik dan Bersahaja,Bangka: Madania Center Press, 2019; Rusydi Sulaiman dan Endang Kusniati (Ed.), Bhinneka Tunggal Ika dalam Bingkai Harmoni Umat

\footnotetext{
${ }^{17}$ Zulkifli, Kontinuitas Islam Tradisional di Bangka, (bangka: Siddik Press, 2007), p. 12
} 
Beragama di Bumi Serumpun Sebalai, Bangka: Madania Center Press, 2019. Literaturliteratur tersebut dirasakan sangat urgen keberadaannya untuk dukungan kelengkapan sumber, selebihnya penguatan sejarah kepulauan Bangka-Belitung.

Terkhusus tentang perkampungan di Bangka, ditemukan beberapa karya Akhmad Elvian adalah: Pangkalpinang Kota Pangkal Kemenangan, 2005; Setengah Abad Kota Pangkalpinang (2006); Toponim Kota Pangkalpinang, 2009; Organisasi Sosial Suku Bangsa Melayu Bangka, 2010; Kota kapur dalam Lintasan Sejarah Bahari, 2011; dan Kampoeng di Bangka, 2014. Sumber-sumber lain agak sulit ditemulan kecuali sumber lisan yang terkesan kurang akurat karena sangat subjektif dan sering berubah-ubah. Namun demikian, kita seringkali terbuai oleh uraian lisan seseorang yang mengaku lebih memiliki otoritas tentang sejarah Bangka.

Sejarah tidak sekedar,"memorie vak" (hafalan), peristiwa atau kejadian masa lalu yang kemudian diungkapkan kembali. Sebagaimana diungkapkan oleh John Tosch dalam bukunya,"the Pursuit of History", bahwa "History is collective memory, the storehouse of experience through which people develop a sense of their social identity and their future prospect" (Sejarah adalah memori kolektif, gudang pengalaman dimana masyarakat mengembangkan rasa identitas sosial dan kemungkinan di masa depan hidup mereka). ${ }^{18}$ Dipastikan ada pesan yang terkandung dalam setiap peristiwa sejarah, yaitu cita-cita kemanusiaan. ${ }^{19}$ Maka pengungkapan data dan fakta sejarah perlu diperkuat dengan konsep dan kerangka teoritik tertentu. ${ }^{20}$

Hubungannya dengan sejarah kampung di Bangka, diperlukan data dan fakta akurat dan dapat dipertanggungjawabkan secara ilmiah. Maka dalam makalah ini perlu dipaparkan gagasan tentang: " Dinamika Peradaban Kampung di Bangka" dengan dukungan literatur sebelumnya. Apapun yang dihasilkan penulis selalu in process-tidak pernah sempurna. Mungkin saja akan muncul karya sejarah tertentu yang lebih berkualitas. Tulisan ini meliputi beberapa sub-bahasan, yaitu: pendahuluan, filosofi

\footnotetext{
${ }^{18}$ John Tosch, the Pursuit of History: Aim, Method and New Direction in The Study of Modern History, (London and New York: Longman, 1984), p. 1

${ }^{19}$ Statemen tersebut sesuai dengan firman Allah dalam QS, Yusuf (12):111, "Sesungguhnya pada kisah-kisah mereka itu terdapat pengajaran bagi orang-orang yang mempunyai akal. Al-Qur'an itu bukanlah cerita yang dibuat-buat, akan tetapi membenarkan kitab-kitab yang sebelumnya dan menjelaskan segala sesuatu,dan sebagai petunjuk dan rahmat bagi kaum yang beriman".

20 Sartono Kartodirdjo, Pendekatan Ilmu Sosial dalam Metodologi Sejarah (jakarta: Gramedia Pustaka Utama, 1993), p. 3
} 
kampung, situs arkeologis di Bangka, kampung di Bangka dan peradaban kampung di Bangka serta kesimpulan.

\section{B. Filosofi Kampung}

Kampung adalah terma yang hampir tidak pernah dipertanyakan orang, diantaranya karena ia sudah dikenal. Kampung atau kampoeng - kata yang digunakan penulis mengandung pengertian berkampung, berhimpunnya keluarga-keluarga batih (keluarga inti) dalam kelompok untuk mengatasi masalah secara bersama. ${ }^{21}$ Istilah tersebut mengindikasikan semangat kehidupan komunitas tertentu yang terhimpun di sebuah kampung, apalagi ketika mereka harus menyelesaikan masalah tertentu seperti pekerjaan berat, darurat atau mendesak yang tidak dapat diatasi oleh keluarga inti. Bila seseorang meninggal dunia (wafat) di sebuah kampung tertentu di Pulau Bangka, beduk di masjid dibunyikan sebagai tanda kematian. Penduduk terdekat bergegas mendatangi rumah duka. Mereka yang berada di kebun atau ladang segera pulang ke kampung hampir tidak ada yang absen, semua ikut serta men-shalati. Hampir pasti penduduk tinggal di kampung pada hari jum'at dan hari-hari selainnya menetap di kebun. Sepertinya takdir kematian penduduk hampir terjadi di hari jum'at saat mereka berada di kampung.

Perihal kampung, penulis tidak mengurai secara detail pembahasannya; makna kampung, asal usul dan sejarah kampung, dan kampung sebagai tempat yang efektif bagi masyarakat untuk melestarikan kehidupannya. Namun demikian penulis memberikan gambaran sosial budaya masyarakat yang bertempat tinggal di kampung. Istilah kampung sepertinya perlu dielaborasi secara mendalam dari pendapat beberapa pakar. Kampung sering kali dimaknai negeri atau wilayah tertentu yang dalam bahasa asing disebut dengan; Country atau Village (bahasa inggris), dan Qoryah atau Quraa dan Balad (bahasa arab), berarti lingkungan tempat tinggal yang damai yang berdomisili didalamnya komunitas tertentu yang memiliki tujuan tertentu. Penduduk kampung tak henti-hentinya berkomunikasi satu sama lain dan hidup berdampingan; saling tolong menolong, sangat peduli, berempati, merasakan apa yang dirasakan yang lain. Perihal kampung dan negeri yang damai, lihat QS, al-A'raaf (7):96, "Jikalau Sekiranya penduduk

\footnotetext{
${ }^{21}$ Elvian, Kampoeng di, p. vi
} 
negeri-negeri beriman dan bertakwa, pastilah Kami akan melimpahkan kepada mereka berkah dari langit dan bumi, tetapi mereka mendustakan (ayat-ayat Kami) itu, Maka Kami siksa mereka disebabkan perbuatannya". Dan lihat QS, at-Tiin (95):1-3, "demi (buah) Tin dan (buah) Zaitun, dan demi bukit Sinai,. dan demi kota (Mekah) ini yang aman, Sesungguhnya Kami telah menciptakan manusia dalam bentuk yang sebaik-baiknya?. (Yang dimaksud dengan Tin oleh sebagian ahli tafsir ialah tempat tinggal Nabi Nuh, Yaitu Damaskus yang banyak pohon Tin; dan zaitun ialah Baitul Maqdis yang banyak tumbuh Zaitun).

Kampung yang diharapkan sebagai basis peradaban, kenyataannya tidak. Banyak sikap dan perbuatan menyimpang terjadi di kampung, seperti pencurian, pembunuhan, kerusuhan dan konfliks internal dan semacamnya. Penduduk kampung tidak terlalu reserve terhadap pengaruh luar, bahkan lahan-lahan belakang rumah dalam bentuk kelekak dijual dengan harga tidak layak karena beberapa alasan. Kemajuan teknologi menerpa penduduk kampung yang relatif rendah tingkat pendidikannya. Akhirnya kampung berubah menjadi tidak aman seperti sebelumnya.

\section{Situs Arkeologis di Bangka}

Satu kegiatan yang dilakukan para arkeolog untuk menguak jejak sejarah masa lampau adalah ekskavasi, yaitu melakukan penggalian terhadap artefak-artefak sebagai benda sejarah yang sangat berharga. Hal tersebut menunjukkan bahwa pernah berlangsungnya sebuah kebudayaan dan peradaban tertentu pada kurun waktu tertentu di masa lalu.

Diantaranya sarana tulis berupa prasasti yang dipahatkan/ dituliskan pada batu logam, kropak/daun lontar, kayu, tulang dan pada berbagai sarana lainnya atau juga berupa tulisan pada batu nisan misalnya yang mengindikasikan waktu masa perjuangannya tokoh tertentu. ${ }^{22}$ Benda-benda sejarah tersebut sangatlah penting keberadaannya sekaligus menjadi bukti autentik sejarah yang dapat dijadikan pijakan

\footnotetext{
${ }^{22}$ Prasasti berasal dari kata dalam Bahasa Sanksekerta yang bermakna pujian, namun kemudian berkembang dan berubah makna menjadi piagam, maklumat dan surat keputusan, undang-undang atau tulisan. Para arkeolog menyebutnya,"inskripsi". Yaitu kata-kata yang diukirkan pada batu monumen atau dicap pada uang logam, medali atau piala. Umumnya prasasti lebih dikenal dengan sebutan batu bertulis atau batu bersurat. Elvian, Kota Kapur dalam Lintasan Sejarah Bahari, (Pangkalpinang, Dinas Kebudayaan, Pariwisata, Seni dsan Budaya, 2011), p. v .
} 
sejarah bagi generasi berikutnya. Dengan media tersebut akan diketahui beberapa data dan fakta sejarah yang memuat hal tertentu sehingga memmotivasi komunitas sesudahnya dalam berbuat dan bersikap.

Bila dikaitkan dengan sejarah Pulau Bangka masa lalu, juga telah ditemukan beberapa bukti fisik menunjukkan bahwa sudah ada komunitas tertentu yang menetap dengan aktifitas tertentu pula. Kenyataan itu menegaskan bahwa lalu lintas laut sejak awal sudah dimanfaatkan untuk pelayaran. Menurut Abdullah Idi, bahwa sekitar tahun 1320, utusan Mahapatih Gajah Mada dari Kerajaan majapahit datang ke Bangka dan melakukan perjalanan dari Desa Ponggor di kaki Gunung Menumbing (Muntok) menuju kaki Gunung Maras, terus ke desa Panji di Bangka Utara hingga sampai di Bangkakota di Bangka Selatan. Ia mengangkat kepala-kepala kampung di sepanjang daerah yang dilewati dan mengajarkan mereka cara mengatur pemerintahan serta cara beradat istiadat. ${ }^{23}$ Namun tidak jelas berapa lama Bangka berada dibawah kekuasaan Majapahit yang runtuh sekitar tahun 1520. Setidaknya istilah Tumenggung dan Patih yang digunakan mengindikasikan adanya pengaruh kerajaan tersebut terhadap Pulau Bangka.

Berikut ini diuraikan bukti - bukti arkeologis dan peninggalan sejarah yang terdapat di Pulau Bangka, yaitu:

\section{Benteng Kotakapur}

Menurut kronik Cina, pada abad ke-7 M telah ditemukan di Bangka Mo Ho Hsin antara Shilifoshin (Sriwijaya) dan Hong-Ling (Jawa) yang terletak di Kotakapur; di pantai barat Bangka (di pantai Selat bangka), tepatnya di muara Sungai Mendu, sehingga memotivasi Raja Sriwijaya Dapunta Hyang Sri Jayanasa membangun prasasti persumpahan di Kotakapur sebagai ancaman bagi mereka yang memusuhi Sriwijaya, yang kemudian disebut, "Prasasti Kotakapur". ${ }^{24}$

Ditemukannya sebuah prasasti di Kotakapur sudah pasti menyisakan pertanyaan bagi ahli sejarah; siapa yang menemukan, apa isi tulisan dan dengan bahasa apa, serta nilai-nilai apa yang terkandung didalamnya? Ternyata tidak sekedar prasasti, namun di tempat tersebut di pulau Bangka ini ditemukan sebuah lokasi khusus semacam benteng,

\footnotetext{
${ }^{23}$ Abdullah Idi, Bangka: Sejarah, p. 19

${ }^{24}$ Abdullah Idi, Bangka: Sejarah, p. 18
} 
disebut benteng Kotakapur. Sudah pasti situs tua tersebut menunjukkan adanya kehidupan komunitas tertentu yang berlangsung cukup lama pada masa kekuasaan Sriwijaya yang beragama Budha atau bahkan mungkin sebelum masa tersebut.

Prasasti Kotakapur ditemukan oleh JK. Meulen pada bulan Desember 1892, kemudian diteliti oleh Prof. Dr. Hendrik Kem (ahli efigrafi) tahun 1913. Hasil pembacaannya disempurnakan oleh George Coedes pada tahun 1918, dan selanjutnya secara intens ditekuni oleh Tim Peneliti Pusat Arkeologi Nasional Jakarta sejak tahun 1993. ${ }^{25}$ Prasasti tersebut berbentuk lingga bersegi enam (heksagonal) dengan ketebalan $18 \mathrm{~cm}$, tinggi 1,77 m, lengkap dengan alasnya berbentuk seperti yoni dengan panjang 90 $\mathrm{cm}$, lebar $52 \mathrm{~cm}$ dan tinggi $17 \mathrm{~cm} .{ }^{26}$ Prasasti yang bertuliskan huruf atau aksara Pallawa berbahasa Melayu Kuno menunjukkan bahwa penduduk setempat telah menggunakan bahasa tersebut sebagai alat berkomunikasi. Sungai Menduk yang panjangnya kira-kira $26.500 \mathrm{~m}$ adalah sungai yang menghubungkan masyarakat Kotakapur dengan dunia luar, seperti ibukota dan kota-kota lain Kerajaan Sriwijaya serta wilayah di daratan Asia Tenggara. Berdasarkan penelitian tahun 2007 yang dilakukan oleh Balai Arkeologi Palembang, Balai Pelestarian Peninggalan Purbakala Jambi serta Dinas Pariwisata Seni dan Budaya kabupaten Bangka telah ditemukan kepingan sisa-sisa perahu yang terbuat dari jenis kayu besi atau kayu ulin berasal dari abad ke-7 M di dua tempat; pertama, lokasi

\footnotetext{
${ }^{25}$ Beberapa lembaga telah lakukan ekskavasi terhadap situs benteng Kotakapur, yaitu: Tim Peneliti Ecole-francaise Orient dan Pusat Penelitian Arkeologi nasional pada tahun 1994 dan 1996, balai Arkeologi Palembang pada tahun 1995, balai Arkeologi palembang bekerjasama dengan balai pelestarian Peninggalan Purbakala Jambi serta Dinas Pariwisata Seni dan Budaya Kabupaten Bangka pada tahun 2007 . Selanjutnya tahun 2010, dilakukanlah studi mintakat dan kelayakan kawasan situs kotakapur yang melibatkan Dinas Kebudayaan dan Pariwisata Propinsi Kep. Bangka Belitung, Dinas Kebudayaan dan Pariwisata Kab, Bangka, Dunas Pekerjaan Umum Propinsi Kep, Bangka Belitung, Bappeda Kaabupaten Bangka, Kementerian Kebuyaan dan Pariwisata, Balai Pelestarian Peninggalan Purbakala Jambi, balai Arkeologi palembang dan Pusat Penelitian dan pengembangan Arkeologi nasional. Lihat dalam Elvian, Kotakapur dalam...., p. xiii

26 Muatan prasasti menunjukkan bahwa sang Budha memberikan makna memberikan penghormatan terhadap penjuru dunia; arah timur adalah simbol penghormatan pada orangtua; arah barat adalah simbol penghormatan pada isteri dan anak (keluarga); arah selatan berarti simbol penghormatan pada guru; arah utara berarti simbol penghormatan pada sahabat dan sesama; arah atas adalah simbol penghormatan pada pertapa dan brahmana; arah bawah merupakan simbol penghormatan pada para pelayan.
} 
alur Sungai Kupang atau Air Pancor yang membelah kawasan situs dan bermuara di Sungai Menduk. ${ }^{27}$ Kedua, lokasi sekitar 500 m barat Sungai Kupang. ${ }^{28}$

Disebut kota untuk wilayah kecil Kotakapur karena memang telah dihuni oleh penduduk tertentu dan secara geografis memiliki posisi yang sangat strategis, berbatasan dengan kawasan rawa-rawa disebelah timur dan berbatasan dengan hutan desa serta di bagian selatan Desa Kotakapur merupakan kawasan perbukitan; Bukit Petaling, Bukit Besar dan Bukit Klidang. Keletakan Kotakapur menurut Elvian, mirip dengan keletakan kota-kota kuno yang didirikan di Nusantara. Ia dipilih berdasarkan pertimbangan pemenuhan aspek-aspek kota umumnya. ${ }^{29}$ Kotakapur dimaksud adalah dinding atau tembok yang memiliki benteng (tempat pertahanan). Di lokasi situs temuan prasasti terdapat sisa-sisa dinding yang mengelilingi benteng, bahkan pada sisi barat daya yang merupakan ujung dari benteng tanah di Desa Kotakapur terdapat gundukan tanah yang berdiri sejajar merupakan lereng bukit yang dijadikan bagian dari benteng-benteng Kotadualapis. ${ }^{30}$

Batu prasasti Kotakapur berasal dari daerah luar Bangka karena batu sejenis tidak ditemukan di pulau tersebut saat itu. Selain bangunan benteng tanah, ditemukan di situs Kotakapur sisa struktur bangunan candi, fragmen beberapa arca Wisnu, potongan tangan dengan atribut trompet kulit kerang dan potongan kaki, yoni dari bahan batu. Arca Wisnu berbentuk mahkota seperti slinder mirip arca Wisnu di Khmer dari masa Pra Angkor. Barang-barang lain adalah terak logam, perhiasan dari emas dan pecahan keramik dari Cina Selatan abad ke-12 dan 13 (Dinasti Sung), wajan dari besi dan batu putih berbentuk

27 Sungai Menduk adalah sungai yang berhulu di Desa Terak, Kace dan Cengkok Abang yang melintasi daerah Petaling dan bermuara dai Desa Penagan. Sungai Menduk digunakan sebagai media transportasi dengan adanya suak-suak, seperti Suak Rukam, Suak kotakapur, Suak Penagan, Suak Menduk dan Suak Petaling. Suak-suak tersebut berfungsi sebagai tempat kapal berlabuh dan dimanfaatkan untuk menyelamatkan diri dari Bangka ke Palembang. Desa Petaling juga dijadikan pusat untuk mengunjungi desa-desa lain seperti Kotakapur, Penagan dan Menduk menggunakan jalur Sungai Menduk tersebut. Ahmad Sukri Ahkap, Mitos dalam Pemanfaatan Hutan Kawasan Lelap Menduk dan Sungai Menduk Desa Petaling, dalam Buku Bunga Rampai, Kelekak Sejarah bangka, (Bangka: Dinas Kebudayaan dan Pariwisata Kabupaten Bangka, 2015).,p.362

${ }^{28}$ Elvian, Kotakapur dalam, p. 18-19

29 Kota-kota kuno umumnya berada di tepi pantai, di tepi sungai atau di lemah-lembah yang dilengkapi dengan berbagai sarana prasarana, baik untuk kepentingan politik (istana kantor), keamanan (bangunan benteng), ekononomi (bangunan dermaga dan pelabuhan),keagamaan (candi atau arca), maupun untuk pemenuhan kebutuhan hidup yang lain. Elvian, Kotakapur dalam, p. 19-20

${ }^{30}$ Elvian, Kotakapur dalam, p. 22-23 
bujur sangkar. ${ }^{31}$ Tinngi tanah benteng adalah 2,5 meter dan panjang sekitar 1,7 meter dengan bentuk melengkung. Di sisi timur terdapat bagian benteng yang ada gundukan dan celah sebagai pintu keluar masuk benteng. Dan adapun prasasti Kotakapur mirip bangunan menhir pada tradisi Megalithikum dan secara umum berbeda dengan prasastiprasasti peninggalan Kerajaan Sriwijaya yang bentuk bulan dan lonjong. ${ }^{32}$

\section{Bangkakota}

Ketika di Pulau Bangka ditemukan beberapa benteng, juga terdapat benteng di Bangkakota. Benteng tersebut umumnya dibangun sebagai media pertahanan pada masa penjajahan Belanda terbuat dari batu, kecuali benteng Kotakapur yang terbuat dari tanah sudah ada pada masa kekuasaan kerajaan Sriwijaya.

Sulit digali perihal awal pemukiman penduduk di Bangkakota karena tidak ditemukan data dan fakta sejarah yang akurat yang mengindikasikan hal tersebut. Namun, dipilihnya daerah tersebut sebagai pusat pemerintahan oleh kesultanan Johor dan Kesultanan Banten Islam sangatlah beralasan. Berdasar uraian sebelumnya bahwa Bangkakota merupakan daerah yang sudah dilewati oleh Mahapatih Gajah Mada dari Majapahit. Artinya daerah ini pasti memiliki nilai lebih tersendiri bagi para pendatang.

Secara geografis, Bangkakota merupakan wilayah bagian kabupaten Bangka Selatan yang tidak jauh dari pesisir pantai. Penduduk Bangkakota yang secara territorial saat ini sebagai desa saja memiliki perofesi nelayan, penambang timah dan juga pekebun sawit. Mereka umumnya pendatang dari seberang, yaitu Sumatera Selatan. Berdasarkan data arkeologis, ditemukan banyak pemakaman yang bertebaran di desa tersebut tanpa identitas sedikitpun. Terdapat satu dua makam agak permanen; satu makam yang disinyalir Pangeran Sarah, disebut karang Panjang di bibir pantai, dua makam di belakang rumah penduduk yang salah satunya disebut Ratu Bagus. ${ }^{33}$ Tidak jauh dari lokasi Desa Bangkakota, tepatnya di seberang perkebunan sawit ditemukan pemakaman Jatisari yang terdiri dari 9 makam berukuran besar bila dibandingkan dengan makam umumnya. Posisinya berada diatas bukit dan tidak jauh dari bibir pantai.

${ }^{31}$ Elvian, Kotakapur dalam, p. 61-62

32 Elvian, Kotakapur dalam, p. 67-69

${ }^{33}$ Menurut kepercayaan masyarakat setempat, bahwa penyebutan makam tersebut menjadi karang panjang karena berubah ukurannya di malam bulan purnama. Adapun makam yang disinyalir makam Ratu bagus juga memiliki keunikan tersendiri. Burung yang terbang akan jatuh bila posisinya tepat berada diatas makam tersebut. 
Tampak dari sejumlah pemakaman di Desa Bangkakota disimpulkan bahwa sudah ada komunitas sebelumnya yang menetap. Sebagian penduduk menyebutkan bahwa makam Karang Panjang sebenarnya adalah makam Akek Antak - tokoh pemula dalam perspektif orang lom di Pulau Bangka. Hal-hal lama yang tidak jelas identitasnya selalu saja dilekatkan kepada tokoh Akek Antak sebagai tokoh tertentu dalam mitologi masyarakat Bangka. Misalnya juga, tidak jauh dari Bangkakota, yaitu di pantai barat Pulau Bangka ditemukan batu panjang menyerupai guling dan diatas ada batu mirip topi, juga disebut guling dan topi Akek Antak. ${ }^{34}$ Namun tidak begitu jelas alasan penyebutan nama tersebut, kecuali adanya keyakina tertentu.

Sebelum kedatangan utusan Kesultanan Johor di Bangkakota, perairan pantai barat Pulau Bangka juga dipenuhi dengan kegiatan bajak laut yang mengganggu ketenangan penduduk setempat. Sebagian kecil penduduk mengasingkan diri ke lereng bukit dekat Desa Sebagin untuk berlindung mencari keamanan. ${ }^{35}$ Sulit dihubungkan mana yang lebih awal antara penduduk Sebagin dan Bangkakota. Sebagin merupakan bagian dari Desa Rajik. Peradaban di Sebagian dan sekitarnya lebih tinggi, dibuktikan dengan suasana perkampungan dan status ekonomi masyarakat nampaknya lebih baik. Ditemukannya beberapa masjid besar di Rajik menunjukkan bahwa kondisi sosial keagamaan penduduknya lebih maju.

Berbeda dengan Desa Bangkakota yang agak sepi. Mayoritas penduduk saat ini adalah pendatang. Dan hanya ditemukan satu masjid besar di desa tersebut yang umur belum begitu tua. Sepertinya kurang nampak pengaruh penempatan Pangeran sarah oleh Kesultanan Johor dan juga penempatan Bupati Nusantara oleh Kesultanan Banten di Bangkakota sebagai pusat pemerintahan di Pulau Bangka.

\section{Kotawaringin}

Sebagaimana Bangkakota, Kotawaringin juga merupakan daerah yang sempat dilalui oleh Mahapatih Gajahmada pada tahun 1320 M. Sudah pasti dilakukan perjalanan ke daerah tersebut, dikarenakan posisinya yang sangat strategis. Ditemukan tebing atau

${ }^{34}$ Wawancara dengan Syef Syarifuddin, sesepuh di Desa Rajik Simpang Rimba bangka Selatan, Agustus 2016 .

35 Disebut Sebagin karena desa tersebut awalnya merupakan bagian dari Desa Rajik. Secara administratif bahwa pusat desa adalah Rajik yang meliputi beberapa dusun, yaitu: Permis, Sebagin dan Rajik. Desa Rajik sangatlah luas bila dibandingkan dengan desa-desa pada umumnya di Pulau Bangka, dan secara ekonomi penduduknya agak mapan. 
gundukan tanah dibelakang masjid jami' kampung dan seberang sungai yang saat ini sudah terkikis. Tampak masjid tersebut adalah masjid tertua di Kotawaringin. Adapun kondisi sungai sudah kurang memadai, namun kenyataannya masih digunakan untuk mandi oleh anak-anak remaja kampung.

Di posisi lebih kurang 100 meter utara masjid terdapat pemakaman umum kampung; beberapa makam berbeda bentuk nisannya dengan makam-makam lain, dan satu makam tua berada dibawah pohon tua, yaitu Makam Raja Alam Harimau Garang yang dinobatkan sebagai Raja Muda oleh Kesultanan Minangkabau sambil mengamankan Selat Bangka dari ancaman bajak laut yang melakukan prompakan. Makam-makam tua tersebut menunjukkan adanya komunitas yang menetap di Kotawaringin pasca periode Raja Alam Harimau Garang sampai desa tersebut dijamah oleh Bangsa Belanda.

Ditemukannya Masjid Jami' kampung di Kotawaringin menunjukkan bahwa Islam menemukan basisnya yang cukup kuat. Sebagai ulama besar yang menetap satu dekade lebih di Bangka, Syaikh Abdurrahman Siddik pernah singgah dan berdakwah di Kotawaringi. Pasca dakwahnya ditemukan beberapa ustadz memiliki peran kuat dalam penyebaran Agama Islam. Islam Kotawaringin adalah Islam yang bercorak tradisional mengacu dalam pembelajaran keagamaannya pada kitab-kitab salafiyah yang ditulis oleh Syaikh Muhammad Arsyad al-Banjari dari Kalimantan. Tampak dari tingkat kebudayaannya, penduduk Kotawaringin sangat kuat mempertahan sikap ortodoksi keagamaannya dan sangat reserve dari pengaruh-pengaruh luar daerah.

\section{Hasil Pembahasan}

\section{Kampung di Bangka}

Bagaimana bentuk kampung dan sejauhmana kampung tersebut mengalami perubahan dari waktu ke waktu? Kampung adalah nama yang dimunculkan masyarakat tertentu tidak sekedar tempat tinggal, berhubungan dengan keharusan aturan, norma, nilai tertentu yang dibuat berdasarkan konsensus sosial untuk mengatur pola hubungan individu dalam bermasyarakat di wilayah yang bernama kampung. Kampung sesungguhnya identik dengan kerukunan dan dinamika kehidupan komunitas tertentu. Namun belakangan tradisi kampung ditinggalkan, dan banyak orang malu bila dilekatkan kepada mereka kata,"kampung". Kampungan berarti ketinggalan zaman, kolot, 
konservatif, udik, malu-maluin, tidak berperadaban, bertolak belakang dengan dipahami tentang "kota", berarti up to date (modern), trendi, liberal, keren, terhormat dan sangat berperadaban (civilized).

Demikian kampung di Pulau Bangka. Menurut Akhmad Elvian, kampung (kampoeng) adalah wilayah teritorial terkecil di Pulau Bangka dikepalai oleh seorang kepala kampung (gegading). Awalnya kampung terdiri dari 10 sampai 40 bubung rumah yang mengelompok dan dibangun berdasarkan arah mata angin serta tergantung pada tata letak ladang dan "hume". Kesepakatan tersebut merupakan bentuk adaptasi terhadap ekologi hutan tropis yang terbentang luas di Pulau Bangka dan sebagai upaya mengatasi tantangan dalam upaya memenuhi kebutuhan hidup terutama bagi pribumi, Orang Darat dengan mata pencaharian berladang dan mengumpulkan hasil hutan. ${ }^{36}$ Tidak juga jelas konsep kampung yang meliputi beberapa bubung rumah, karena tidak ditemukan makna filosofis yang kuat tentang bubung, hume, tangga, pelepah rumbia untuk atap rumah dan perangkat lainnya. Maka perlu ulasan yang detail tentang kampung, apalagi secara konseptual berbeda dengan kampung-kampung yang berada di daerah lain, seperti Jawa dan Madura.

Sudah pasti bentuk dan fungsi kampung mengalami pergeseran pasca kebijakan Belanda yang mewajibkan penduduk membuat rumah-rumah mereka berderet memanjang di kanan dan kiri jalan. ${ }^{37}$ Setelah itu pada tahun 1865 M, Pulau Bangka terdiri

${ }^{36}$ Elvian, kampoeng di.,hlm. v

37 Ketidakberdayaan Belanda memadamkan pemberontakan Amir merupakan salah satu sebab kebijakan pemukiman penduduk Bangka. Dilakukanlah awalnya pengumpulan penduduk di jalan-jalan besar, namun kurang berhasil. 300 orang penduduk tetap tinggal di ladang-ladang dan selalu terjadi perpindahan usai siklus pertanian ladang, Hutan yang digunakan untuk ladang pertama selama 6 atau 7 tahun,lalu mencari hutan untuk dibabat. Sebelum tahun 1849 dilakukan uji coba Belanda dengan menempatkan 200 orang penduduk di jalan-jalan besar yang sedang dibangun pemerintap.Saat itu ada indikasi keinginan penduduk untuk bermukim sepanjang jalan. Didata kemudian kampung-kampung di Pulau Bangka; antara muntok dan Toboali terdapat 51 kampung (45 kampung baru dibangun), antara Pangkalpinang ke arah utara melalului Roema Bakem sampai Muntok terdapat 22 kampung (20 diantaranya adalah kampung baru); antara Pangkalpinang dan Sungai selan terdapat 7 kampung (6 diantaranya kampung baru); antara Sungai Selan ke Kurau terdapat 7 kampung (3 diantaranya kampung baru); dari Bakem melewati Laijang ke Sungai liat terdapat 7 kampung (terdapat 1 kampung lama). Berdasarkan data Residen Bangka, terdapat 232 penempatan kampung-kampung terdiri dari 99 kampung lama dan 133 kampung baru dengan rincian bahwa setiap 3 pal terdapat kampung kecil dengan rata-rata 20 sd. 30 rumah (80 sd. 100 penduduk), dan setiap 6 pal terdapat kampung besar dengan rata-rata 40 sd. 60 rumah (150 sd. 200 penduduk). Pembentukan kampung di Bangka diikuti dengan pengorganisasian pemerintahan baru. Usaha pemindahan penduduk di sepanjang jalan nampaknya memiliki tujuan lain, diantara untuk menmbah kekurangan tenaga kerja proyek pembangunan jalan dan infra struktur lainnya. Lihat Erman, Menguak Sejarah Timah.,hlm. 3-5 
dari sepuluh distrik, yaitu: Distrik Muntok, Jebus, Sungailiat, Merawang, Belinyu, Pangkalpinang, Kepulauan Lepar, Sungai Selan, Toboali dan Koba. ${ }^{38}$ Pengelompokan tersebut sedikit banyak menyalahi konsep tata letak dan prinsip yang telah diberlakukan sebelumnya. Akhirnya masyarakat pribumi mengalami beberapa hambatan dalam berinteraksi, karena jarak antar rumah terlalu dekat (membelakangi hutan kelekak dan menhadap jalan raya. Pola kehidupan masyarakat menjadi tidak lebih dinamis dan selalu dalam pengawasan ketat Belanda. Agak berbeda dengan posisi kampung atau perkampungan di pusat-pusat distrik yang relatif tertata rapi.

Jika pada tahun 1854 terdapat sebanyak 203 kampung, maka tahun 1883 menciut menjadi 184 kampung dan tahun 1896 menurun angkanya menjadi 143 kampung. Dan pasca kebijakan desentralisasi kolonial bertambah menjadi 169 kampung. Tatanan kampung tersebut dikeluarkan kebijakannya karena Belanda lebih mementingkan perusahaan timah dari pada kebutuhan penduduk setempat. ${ }^{39}$ Penduduk beralih menjadi penanam karet dan lada di kebun-kebun yang jauh dari tempat tinggal mereka di kampung. Mereka relatif lebih sejahtera daripada situasi sebelumnya.

Respons terhadap hal tersebut, Kolonial Belanda membuat kebijakan tentang pembangunan rumah, jarak antar rumah, pekarangan, pepohonan dan buah-buahan untuk tujuan kesehatan, menghindari wabah penyakit yang sedang dialami penduduk. ${ }^{40}$ Begitu banyak rumah-rumah dibangun saat itu menggantikan rumah-rumah lama bersamaan dengan mahalnya harga komoditi lada dan karet. Dalam catatan Engelenberg sebagaimana dikutip oleh Erwiza Erman, bahwa rumah-rumah dibangun di daerahdaerah tertentu: Pangkalpinang, Merawang dan Sungai Selan. ${ }^{41}$ Terkadang muncul sikap tidak setuju tokoh setempat, namun tidak kuasa melawan lebijakan pemerintah pusat di Jakarta yang mendelegasikan otoritas nya kepada pejabat-pejabat kampung. Mereka yang diangkat tidak otomatis dituruti penduduk karena mereka bukan kepala adat yang

38 Sebelumnya hanya terdapat sembilan distrik di pulau bangka dengan 163 kampung. Pasca Perang bangka yang dipimpin oleh Depati Amir tahun 1851 M, Pulau Bangka dijadikan sebuah koloni Belanda yang regelmatij dari keseluruhan koloni Belanda di Hindia Belanda. Lihat dalam Elvian, Kampoeng di.,hlm. 1 dan hlm. 89.

${ }^{39}$ Erman, Menguak Sejarah Timah Bangka-Belitung, p. 8

${ }^{40}$ Erman, Menguak Sejarah Timah Bangka-Belitung, p. 9

${ }^{41}$ Erman, Menguak Sejarah Timah Bangka-Belitung, p. 9 
dianggap mampu memecahkan masalah yang dihadapi. Sikap protes atas kesewenangwenangan tersebut lambat laun bermunculan.

Disamping perkampungan penduduk melayau, komunitas Tionghoa juga disiapkan perkampungan, yaitu kampung Cina yang terletak dekat tambang timah atau rumah-rumah pencairan. Lokasinya jauh dari pangkal-pangkal Bangka atau dari ibukota distrik tambang. Awalnya rumah kongsi yang dihuni kepala kongsi dan penambang timah dilengkapi dengan altar tempat sembahyang dan kebun-kebun sayur dan peternakan. ${ }^{42}$ Satu hal yang mebedakannya dengan perkampungan Melayu, bahwa setiap rumah kampung Cina sangat luar dan berada jauh dari keramaian. Kenyataannya bersamaan dengan bertambah jumlah penduduk dan pemekaran wilayah, kampung-kampung Cina tersebut kemudian menjadi wilayah yang sangat strategis. ${ }^{43}$ Dalam perkembangannya penduduk Cina kurang membaur dengan penduduk lokal. Mereka masih menggunakan Bahasa Cina (dialek Cina atau Mandarin) dan juga masih menganggap mereka sebagai orang Cina; berhubungan dengan Cina, berorientasi ke Cina, baik secara kultural maupun politis. ${ }^{44}$

Belakang ini, tatanan kampung kemudian mengalami perubahan, menjadi lebih baik. Tidak semua rumah dalam posisi berderet lagi, sebagian dibangun di posisi masuk kedalam setelah sebelumnya dibuka jalan masuk. Bangunan-bangunan masjid bertambah (lebih dari satu buah) dan sekolah juga menghiasi lingkungan dalam kampung di wilayah pedesaan. Beberapa pesantren juga bermunculan di kampung-kamoung besar yang memiliki basis agama Islam kuat. Sebaliknya bangunan gereja dan kelenteng tidak mudah terbentuk karena sikap ortodoksi masyarakat setempat.

${ }^{42}$ Erman, Menguak Sejarah Timah Bangka-Belitung, p. 11

43 Kehadiran China di Bangka ketika Bangka berada dibawah kekuasaan Sriwijaya, namun formalnya adalah awal abad ke XVIII M, yaitu saat dibukanya tambang timah di pulau tersebut. Dan pada masa Kesultanan Palembang, kuli-kuli China terus berdatangan untuk dipekerjakan di tambang timap.Koneksi khusus antara China Selatan dan Asia Tenggara telah memicu proses pengadaan emigran. Petani-petani China memerluka dukungan sistem agar dap berintegrasi dengan Asia Tenggara. Mereka mengatur kegiatan tambang dan dengan tujuan propit agar dapat mengatur perpindahannya. Di abad ke XIX, impor kuli China diatur dan dibayar oleh Eropa. Beberapa faktor yang mendasari emigrasi tersebut adalah: kemiskinan, krisi politik dan ekonomi dalam negeri China yang bersamaan dengan eksploitasi ekonomi Barat di Asia Tenggara serta faktor transportasi. Abdullah Idi, Bangka: Sejarah Sosial Cina-Melayu, (Yogyakarta: Tiara Wacana, 2011), p. 30-33

${ }^{44}$ Idi, Bangka: Sejarah Sosial, p. 33 
Kondisi geografis tersebut memotivasi penduduk setempat untuk segera berintegrasi secara sosial antar sesama bahkan dengan para pendatang dari daerah lain. Pernikahan yang dulunya di kampung-kampung tertentu sangat bersifat, next-doormarriage (kawin dengan tetangga dekat rumah) lambat laun laun meluas menjadi antar kampung, bahkan antar pulau. Dialek Melayu yang sangat kental menurun bersamaan dengan pembaharuan pearadaban kampung di hampir seluruh Pulau Bangka.

Namun demikian kampung-kampung di Bangka memiliki karakteristiknya sendiri yang senantiasa dipertahankan oleh secara ketat oleh komunitasnya. Pola bentuk kampung yang memiliki pemandian khusus ujung kampung, masjid pinggir jalan, rumah panggung dengan tangga kayu dan stribut-atribut tertentu mencirikan kampungkampung melayu di pedesaan. Bila digali, tentu tersirat didalammnya nilai-nilai kearifan lokal yang menjunjung tinggi nilai-nila Islam sebagai agama penduduk.

\section{Penguatan Peradaban Kampung di Bangka}

Membahas sebuah kampung sebenarnya membahas proses peradaban yang berlangsung di kampung tersebut. Komunitas tertentu (yang menetap di sebuah kampung) dengan potensi yang dimiliki dituntut untuk melakukan perubahan secara signifikan dari tiada menjadi ada, berkembang dan kemudian eksis, memiliki prinsip sehingga terjaga dari pengaruh apapun.

Kebudayaan dan peradaban mengalami dinamikanya sendiri-sendiri di wilayah tertentu dalam sebuah komunitas sosial menyatu, saling mempengaruhi atau sebaliknya clash sehingga memunculkan peradaban baru, termasuk kampung sebagai teritorial kecil yang dihuni masyarakat. Bagaimana dengan peradaban kampung di Bangka, aspek yang sebenarnya ingin ditekankan? Kampung yang dulunya digagas oleh tokoh lokal kemudian harus berbenturan dengan kebijakan yang merubah posisi kampung. Kampung adalah wilayah tertentu yang mesti diperkuat peradabannya.

Peradaban adalah bagian dari kebudayaan, hakikatnya memiliki wujud-wujud tertentu, yaitu wujud ideal, wujud kelakuan dan wujud benda. ${ }^{45}$ Peradaban adalah

${ }^{45}$ Tiga wujud tersebut adalah: Pertama, wujud ideal, wujud kebudayaan sebagi suatu kompleks ide-ide, hgagasan, nilai-nilai, norma-norma, peraturan dan sebagaianya: kedua, wujud kelakuan, wujud kebudayaan sebagai kompleks aktifitas kelakuan berpola dari manusia dalam masyarakat; dan ketiga wujud benda yanitu wujud kebudaayn sebagai benda-benda hasil karya. Badri Yatim, Sejarah Peradaban 
kesusastraan, identik dengan adab dan etika. Dan adab mengandung pengertian pengetahuan yang membawa pada budaya intelektual tingkat tinggi yang berimplikasi pada hubungan sosial yang berkualitas dan halus. Bila diamati secara mendalam, banyak hal menyangkut peradaban masyarakat Bangka yang mengalami penyimpangan dari konsep sebelumnya. Bisa jadi hal tersebut dipengaruhi oleh kebijakan Belanda yang cukup lama mengkungkung masyarakat atau pengaruh dari akibat dari eksodus masyarakat luar pulau yang terus-menerus mengalir tanpa pengawasan yang ketat. Peradaban baru menimbulkan clash sebagaimana diurai muncul dalam bentuk sikap, cara berfikir, prinsip-prinsip hidup, dan semacamnya, sehingga menjadi bertolak belakang dari hakekat peradaban kampung di Bangka. ${ }^{46}$

Beberapa terma yang secara kultural telah mempengaruhi penduduk lokal adalah: taipau (sombong, tidak apa adanya), dak kawa nyusah (malas bekerja), sebasing (sembrono), ngerinding (minta-minta, berharap pemberian orang lain), belagak (angkuh dan sombong), kamkai (menganggap sepele sesuatu), ngerameng (tidak beraturan) dan lainnya. Tanpa mempersoalkan asal usulnya, setidaknya terma-terma tersebut menghambat lajunya proses peradaban.

Ketika mayoritas penduduk terdiri dari suku melayu yang beragama Islam dikenal memiliki karakter kuat dalam kehidupan sosial budaya setempat, ${ }^{47}$ maka penduduk lain yang bukan melayu berbeda peradabannya dengan peradaban melayu. Mungkin saja akan terjadi pembauran sehingga salah satu lebih dominan mempengaruhi yang lain. Hal-hal yang selama ini diyakini penduduk lokal lambat laun terkikis.

Tentunya diperlukan proses penguatan sikap saling memahami antar yang memiliki peradaban tersebut. Maka sudah saatnya kita kembali merevitalisasi bentukbentuk peradaban: kearifan lokal, tradisi positif tertentu, dan semacamnya, yang di digagas oleh para pendahulu, dan sebaliknya tidak mudah bergeser tanpa alasan objektif tertentu. Peradaban kampung di Bangka memiliki kekuatan tersendiri untuk menginspirasi kebesaran komunitasnya menjadi lebih baik dan bijak. Perdaban yang baik

Islam (Jakarta: PT Raja Grafindo Persada, 2008), p. 1. Dilekatkan kepadanya ilmu pengetahuan dan tekhnologi tinggi.

${ }^{46}$ Hasan Asari, Menguak sejarah mencari ibrah: Risalah Sejarah Intelektual Muslim Klasik (Bandung: Cita Pustaka Media, 2006), p. 83.

${ }^{47}$ Zulkifli, Kontinuitas Islam tradisional di Bangka (bangka: siddiq Press, 2007), p. 5 
adalah khazanah atau sumber sejarah yang snagat bermakna, apalagi peradaban menunjukkan baik atau buruknya sebuah masyarakat.

\section{E. Kesimpulan}

Terlepas dari kekurangan yang dimiliki, kita tentunya terus berusaha untuk menjadi lebih baik dan lebih dinamis. Menulis tentang sejarah Bangka agak berat karena terbatasnya literatur yang terkait apalagi menyajikannya secara sistematis dan lugas sehingga enak dibaca. Dan apa yang telah kita lakukan dengan penuh pengorbanan terkadang tidak lupat dari kritikan orang lain.

Selain lagi dalam menulis sejarah, beberapa pendekatan harus dilakukan, yaitu: pertama, memperhatikan lima unsur (apa atau siapa, dimana, kapan, bagaimana dan mengapa); kedua, berusaha bersikap objektif dan bijak dalam menyikapi realitas sejarah dan menghindari keberpihakan subjektif; ketiga, memberikan deskripsi sumber sejarah sehingga memotivasi kita untuk mengkritisinya kemudian; keempat, mengungkapkan aspek tertentu dalam sejarah, yaitu: Kampoeng di Bangka sehingga memberikan nuansa tersendiri. Mudah-mudahan tulisan ini dapat memberikan inspirasi buat peminat sejarah, khususnya kita yang berdomisili di kepulauan ini. Wassalam, barokakumullah, amiin ya Rabb al-'Aalamiin. 


\section{DAFTAR PUSTAKA}

Abdullah Idi, 2011, Bangka: Sejarah Sosial Cina-Melayu, Yogyakarta: Tiara Wacana.

Akhmad Elvian, 2014, Kampoeng di Bangka, Pangkalpinang: Dinas Kebudayaan, Parawisata, Pemuda dan Olah Raga.

Badri Yatim, 2008, Sejarah Peradaban Islam, Jakarta: PT Raja Grafindo Persada.

Erwiza Erman, 2009, Menguak Sejarah Timah Bangka Belitung: dari Pembentukan Kampung ke Perkara Gelap, Yogyakarta: Penerbit Ombak.

Hasan Asari, 2006, Menguak Sejarah Mencari Ibrah: Risalah Sejarah Intelektual Muslim Klasik, Bandung: Cita Pustaka Media.

John Tosch, 1984, the Pursuit of History: Aim, Method and New Direction in The Study of Modern History, London and New York: Longman.

M. Dien Madjid, dkk., 2015, Kelekak Sejarah Bangka, Bangka: Dinas Kebudayaan dan Pariwisata Kabupaten Bangka.

Rusydi Sulaiman, dkk., 2019, KH.Ja'far ADDARI: Ulama Kharismatik dan Bersahaja, Bangka: Madania Center Press.

Sartono Kartodirdjo, 1993, Pendekatan Ilmu Sosial dalam Metodologi Sejarah, Jakarta: Gramedia Pustaka Utama.

Teungku Sayyid Deqy, 2014, Korpus Mapur dalam Islamisasi Bangka, Yogyakarta: Ombak. Zulkifli, 2007, Kontinuitas Islam tradisional di Bangka, Bangka: Siddiq Press. 